\title{
Makna dan Sumber Kebahagiaan Remaja Suku Minangkabau
}

\author{
Niken Hartati \\ Universitas Negeri Padang \\ ఏ e-mail: hartati.unp@gmail.com
}

\begin{abstract}
Abstrak
Penelitian ini melibatkan subjek yang berafiliasi dengan suku Minangkabau, berusia remaja, yang terdiri dari representasi subjek berusia remaja dengan tingkat pendidikan SMP dan SMA. Penelitian ini sendiri bertujuan untuk menggali makna kebahagiaan berdasarkan perspektif subjek dan mengenali sumber-sumber kebahagiaannya sekaligus sumber ketidakbahagiaannya. Penelitian ini menggunakan pendekatan kualitatif yang dilakukan dengan metode survei dengan kuesioner terbuka (open ended questionnaire) dengan mengajukan pertanyaan tentang definisi kebahagiaan dan hal-hal apa saja yang membuat subjek merasa bahagia dan hal-hal apa saja yang membuat subyek merasa sangat tidak bahagia. Analisis deskriptif dilakukan dengan menggunakan tabel frekuensi. Hasil penelitian menunjukkan bahwa kebahagiaan remaja bersumber dari keluarga, prestasi, teman, rekreasi, materi dan aktivitas religi. Sumber ketidakbahagiaannya juga keluarga, prestasi, teman, orang lain, kecelakaan, bencana alam, dan diri sendiri. Makna kebahagiaan dibagi menjadi beberapa dimensi yaitu bentuk kebahagiaan, sumber kebahagiaan, status kebahagiaan, dan manfaat.
\end{abstract}

Kata Kunci: kebahagiaan, remaja, minang

Copyright (C) 2017 IICET (Indonesia) - All Rights Reserved

Indonesian Institute for Counseling, Education and Theraphy (IICET)

\section{PENDAHULUAN}

Penelitian mengenai kebahagiaan, saat ini banyak mendapatkan perhatian para peneliti (Snyder \& Lopez, 2007; Koopmans, dkk., 2010; Brockmann \& Delhey, 2010) dan dibutuhkan oleh para pembuat kebijakan publik pada umumnya, karena pengukuran terhadap kebahagiaan merupakan salah satu indikator bagi keberhasilan suatu program intervensi yang ditujukan bagi masyarakat (Cummins, Lau, Mellor, \& Stokes, 2009; Brockmann \& Delhey, 2010). Selain itu kebahagiaan juga merupakan tujuan hidup manusia (Heady, 2008).

Hal tersebut adalah wajar karena kebahagiaan memiliki berbagai manfaat positif bagi manusia misalnya memiliki kesehatan fisik lebih baik dibandingkan individu tidak bahagia (Honkanen, Honkanen, Koskenvuo, \& Kaprio, 2003; Post, 2005; Koopmans, dkk., 2010; Diener, 2009; Agner, Miller, Ray, Saag, \& Allison, 2010) serta terhindar dari perilaku yang merusak kesehatan seperti merokok, mengonsumsi alkohol dan bunuh diri (Honkanen, dkk., 2003; Valois, Zullig, Huebner, \& Drane, 2004). Kebahagiaan juga berkorelasi dengan rendahnya kematian dan kesengsaraan pada lansia (Koopmans, dkk., 2010). Secara umum, kebahagiaan terkait erat dengan rendahnya permasalahan kesehatan mental seperti depresi (Chaplin, 2006) dan hadirnya kesehatan mental lebih baik (Perneger, Hudelson, \& Bovier, 2004). Kebahagiaan pada remaja berkorelasi dengan rendahnya tekanan sosial (sosiostress), munculnya gangguan klinis serta meningkatnya fungsi intrapersonal dan sikap yang positif terhadap guru (Gilman \& Huebner, 2006).

Dikaji dari rentang perkembangan, kebahagiaan remaja perlu mendapatkan perhatian khusus karena Csikszentmihalyi dan Hunter (2003) mengatakan bahwa masa remaja merupakan masa dengan tingkat kebahagiaan terendah, padahal pada masa tersebut remaja berhadapan dengan usaha pemaknaan kebahagiaan Magen (1999). Penelitian kebahagiaan remaja juga sudah dilakukan di Indonesia, namun belum ada penelitian 
kebahagiaan yang dilakukan dengan subyek remaja beretnis Minangkabau, padahal Minangkabau memiliki budaya yang berbeda dengan budaya lain di Indonesia yang sebagian besar bersifat patriakat. Secara kontekstual, budaya Minangkabau adalah satu-satunya budaya matriakat di Indonesia. Sedikit banyak hal tersebut dapat mempengaruhi perilaku individu yang ada di dalamnya, termasuk remaja beretnis Minangkabau.

Penelitian ini perlu dilakukan untuk memperkaya terbangunnya Psikologi Nusantara dengan memperbanyak penelitian dalam berbagai budaya, termasuk salah satunya Minangkabau. Tujuan penelitian ini adalah menjawab tiga pertanyaan utama penelitian yaitu mengungkap sumber-sumber kebahagiaan, sumbersumber ketidakbahagiaan dan makna kebahagiaan remaja beretnis Minangkabau.

\section{METODOLOGI}

Pengumpulan data penelitian dilakukan dengan metode survei dengan kuesioner terbuka untuk mengungkap sumber-sumber kebahagiaan, ketidakbahagiaan dan makna kebahagiaan remaja beretnis Minangkabau.

\section{Partisipan}

Seluruh subyek penelitian berjumlah 204 orang yang terdiri dari 118 siswa SMP dan 86 siswa SMA. Lebih lengkapnya dapat dilihat pada tabel 1. Berdasarkan tabel tersebut, terlihat bahwa dari 118 siswa SMP, 57 orang berjenis kelamin laki-laki dan 61 orang berjenis kelamin perempuan. Sementara dari 86 siswa SMA, 39 orang laki-laki dan 47 perempuan.

Tabel. 1

Deskripsi subyek penelitian berdasarkan tingkat pendidikan dan jenis kelamin

\begin{tabular}{|c|c|c|c|}
\hline \multirow[t]{2}{*}{ PENDIDIKAN } & \multicolumn{2}{|c|}{ JENIS KELAMIN } & \multirow[t]{2}{*}{ Total } \\
\hline & LAKI-LAKI & PEREMPUAN & \\
\hline SMP & 57 & 61 & 118 \\
\hline SMA & 39 & 47 & 86 \\
\hline & 96 & 108 & 204 \\
\hline
\end{tabular}

\section{Instrumen}

Instrumen yang digunakan dalam penelitian ini adalah Kuesioner terbuka yang merupakan hasil adaptasi yang dilakukan oleh CICP (Center for Indigenous and Cultural Psychology) UGM terhadap Happiness Questionnaire yang disusun dan dikembangkan oleh Uichol Kim namun dimodifikasi dengan menambahkan pertanyaan tentang peristiwa yang sangat tidak membahagiakan remaja, serta pertanyaan atas pengertian kebahagiaan di mata remaja. Pertanyaan yang akan dikaji dalam penelitian ini adalah :

1. Peristiwa yang membahagiakan

Peristiwa yang membahagiakan ialah kejadian yang pernah dialami dan dipersepsikan oleh subjek sebagai sesuatu yang membahagiakan, diperoleh dengan mengerjakan perintah : "Tuliskan dua peristiwa yang membuatmu merasa sangat bahagia" dan menjawab pertanyaan "Pilihlah salah satu peristiwa yang membuatmu paling merasa bahagia"

2. Peristiwa yang sangat tidak membahagiakan

Peristiwa yang sangat tidak membahagiakan ialah kejadian yang pernah dialami dan dipersepsikan oleh subjek sebagai sesuatu yang tidak membahagiakan, diperoleh dengan mengerjakan perintah : "Tuliskan dua peristiwa yang membuatmu merasa sangat tidak bahagia" dan menjawab pertanyaan "Pilihlah salah satu peristiwa yang membuatmu paling merasa bahagia"

3. Makna kebahagiaan

Makna kebahagiaan ialah pengertian kebahagiaan yang dipersepsi oleh subjek, diperoleh melalui jawaban atas perintah "Lengkapilah kalimat berikut ini : Menurut saya, kebahagiaan adalah......."

\section{HASIL DAN PEMBAHASAN}

Penelitian ini bertujuan untuk mengungkapkan sumber-sumber kebahagiaan remaja dengan latar belakang etnis Minang, dilakukan dengan mengevaluasi tiga pertanyaan utama penelitian yaitu : pertama, 
peristiwa apakah yang membuat remaja bahagia; kedua, peristiwa apakah yang membuat remaja merasa sangat tidak bahagia dan apa makna kebahagiaan bagi remaja dengan latar belakang etnis Minangkabau.

Secara umum hasil pengungkapan peristiwa yang membahagiakan remaja beretnis Minang tidak berbeda dengan remaja beretnis Jawa yang digali oleh CICP UGM (Primasari, dkk., 2010; Oetami, dkk, 2010; Anggraeny, dkk, 2010) serta temuan Cahyani (2011) dan Hartati (2012). Temuan tersebut ialah pada munculnya kategori keluarga sebagai peristiwa yang sangat membahagiakan remaja, disusul dengan prestasi. Namun temuan tersebut berbeda dengan temuan Hartati (2012) yang menunjukkan bahwa prestasi menjadi sumber utama kebahagiaan remaja laki-laki, melebihi keluarga. Hal tersebut menguatkan bukti bahwa jika remaja tinggal bersama keluarga dan tidak mengalami keterbatasan akses dengan mereka, maka remaja lebih mungkin memilih keluarga sebagai sumber kebahagiaan di atas kategori lainnya.

Korelasi antara keluarga dengan kebahagiaan telah dibuktikan pada penelitian terdahulu (Casas, dkk., 2008; Casas, dkk., 2007; Cheng \& Furnham, 2004; Furnham \& Cheng, 2000; Setyasari, 2009; Yang, Wang, Li, Teng \& Ren, 2008; Ben-Zur, 2003). Artinya jika remaja memiliki keluarga yang sesuai dengan harapan maka mereka akan bahagia, demikian juga sebaliknya jika keluarga yang dimilikinya tidak sesuai dengan harapan, maka keluarga juga bisa menjadi salah satu sumber ketidakbahagiaan. Hal tersebut juga terungkap dalam temuan penelitian ini, utamanya pada aitem pertanyaan tentang jenis peristiwa yang membuat remaja merasa sangat tidak bahagia. Pada aitem tersebut, keluarga juga menempati urutan pertama peristiwa yang tidak membahagiakan yaitu saat remaja berada jauh dari keluarga maupun saat mengalami permasalahan dalam keluarganya.

Senada dengan keluarga, prestasi juga memiliki dua mata pisau bagi remaja, membahagiakan, sekaligus berpotensi untuk membuat remaja merasa sangat tidak bahagia. Prestasi yang gagal diraih, utamanya prestasi akademik seperti nilai yang jelek, tidak mendapatkan sekolah favorit, tidak naik kelas dan sebagainya, menjadi sumber ketidakbahagiaan remaja. Dapat disimpulkan bahwa prestasi berubah menjadi peristiwa yang sangat tidak membahagiakan apabila remaja tidak dapat meraihnya. Hal ini menunjukkan bahwa remaja memiliki motivasi berprestasi yang cukup tinggi, terlepas dari apakah tujuan prestasi tersebut bagi pemenuhan dirinya maupun bentuk persembahan bagi keluarganya.

Teori yang tepat untuk menggambarkan dinamika prestasi dan kebahagiaan adalah activity theory dimana individu akan merasakan kebahagiaan jika ia telah mengerahkan usaha terbaiknya untuk mengatasi tantangan (Czikzentmihalyi dalam Diener, 2009; Magen, 1999). Prestasi mempersyaratkan usaha-usaha yang harus dilakukan individu. Mulai dari proses pencapaian sampai akhirnya terpenuhi seluruh persyaratan tersebut, individu akan selalu merasakan kebahagiaan. Sebaliknya, jika sasaran yang dituju tidak dapat teraih, maka individu akan mengalami kekecewaan.

Meskipun teman tidak berada pada urutan pertama pendukung kebahagiaan remaja, namun relasi bersama teman yang tidak memuaskan dapat menjadi salah satu sumber ketidakbahagiaan remaja seperti yang ditunjukkan dalam penelitian ini melalui pertanyaan peristiwa apakah yang membuat remaja merasa sangat tidak bahagia. Peristiwa bertengkar dengan teman, dikhianati sahabat dan diejek teman, maupun peristiwa seperti kehilangan teman dan jauh dari teman yang dicintai, ternyata memberikan dampak negatif bagi remaja, berupa perasaan yang sangat tidak membahagiakan. Sehingga dapat disimpulkan bahwa teman masih tergolong figur yang signifikan bagi remaja.

Temuan yang menarik pada peristiwa yang membahagiakan remaja adalah temuan tentang rendahnya pilihan remaja pada aktivitas religi sebagai sumber kebahagiaan, bahkan posisinya di bawah materi. Hal tersebut menjadi menarik karena temuan tersebut senada dengan temuan-temuan lain (Oetami, dkk. 2010; Hartati, 2012; dan Cahyani, 2011). Temuan ini cukup meresahkan karena terdapat dugaan bahwa nilai-nilai religiusitas terlihat kurang realisitis dibandingkan nilai-nilai material yang sifatnya memang konkrit dan dapat diukur langsung. Pendeknya, aktivitas religi memang membahagiakan, namun lebih bahagia jika mendapatkan materi. Penelaahan terhadap budaya kapitalisme yang dimanifestasikan dalam perilaku konsumtif, terlihat sangat dibutuhkan. Sebab materi sebagai cerminan kebahagiaan hedonisme yang bersifat sementara, dapat menghambat remaja untuk mencapai kebahagiaan yang sebenarnya (eudaemonik).

Seperti halnya penelitian terdahulu (Oetami, dkk, 2010; Cahyani, 2011 dan Hartati, 2012), rekreasi atau pemanfaatan waktu luang terlihat cukup membahagiakan remaja meskipun tidak memiliki frekuensi yang 
cukup tinggi. Hal ini menunjukkan bahwa sebagian besar remaja lebih menyukai kegiatan bersama dalam interaksi sosial dibandingkan memanfaatkan waktu untuk pemenuhan kebutuhan pribadi. Benar-benar sebuah representasi budaya kolektivistik.

Selain mengungkap sumber-sumber kebahagiaan remaja, penelitian ini juga mengungkap hal-hal yang membuat remaja tidak bahagia. Secara sekilas telah diulas bahwa sumber utama ketidak bahagiaan remaja terletak pada keluarga, yaitu saat relasi dengan keluarga tidak berjalan seperti yang mereka inginkan. Kemudian prestasi, yaitu saat remaja tidak memperoleh prestasi seperti yang mereka harapkan. Sumber lainnya adalah teman, yaitu saat relasinya bersama teman mengalami masalah. Perlakuan buruk dari orang lain dan guru juga merupakan sumber relasi sosial yang berpotensi membuat remaja tidak bahagia. Bencana alam dan uang, meskipun bukan faktor relasi sosial namun merupakan faktor eksternal yang dapat menyebabkan ketidakbahagiaan. Satu-satunya faktor internal hanya terletak pada kategori diri sendiri yang jumlahnya tidak terlalu banyak. Artinya, dapat disimpulkan bahwa pusat kendali remaja terletak pada kontrol eksternal dibandingkan kontrol internal. Hal tersebut dapat dijelaskan melalui temuan Taylor, Peplau dan Sears (1986) dan Sarafino (1998) yang mengemukakan bahwa gangguan pada relasi sosial eksternal memungkinkan remaja mengalami kurangnya dukungan sosial yang dibutuhkan untuk melekat, integrasi sosial, harga diri dan ikatan yang dapat dipercaya. Hal tersebut otomatis menimbulkan ketidakbahagiaan.

Selain membahas faktor yang membahagiakan dan faktor yang membuat remaja menjadi sangat tidak bahagia, penelitian ini juga mengungkap makna kebahagiaan dalam kehidupan remaja Minang. Makna kebahagiaan dibagi menjadi beberapa dimensi. Dimensi pertama terkait bentuk kebahagiaan. Senada dengan Diener (2009) yang mengemukakan bentuk kebahagiaan sebagai tingginya emosi positif, rendahnya emosi negatif dan kepuasaan hidup, penelitian ini juga menemukan bahwa remaja minang memilih ekspresi jiwa berupa munculnya perasaan positif dan ketiadaan perasaan negatif sebagai bentuk kebahagiaan. Makna kebahagiaan dilihat dari dimensi sumber yaitu bahwa kebahagiaan berasal dari diri sendiri sebagai hasil kesungguhan, keinginan sendiri dan pencapaian keinginan dan kemampuan bersyukur. Kebahagiaan juga bisa bersumber dari sesuatu di luar dirinya seperti anugerah Tuhan, serta kebahagiaan berasal dari interaksi antara individu dengan orang lain yaitu melalui pengorbanan dan usaha membahagiakan ataupun dibahagiakan orang lain. Hal tersebut semakin menguatkan warna budaya kolektivistik di Minangkabau.

Dimensi ketiga dari makna kebahagiaan adalah statusnya bagi kehidupan seseorang. Remaja memutuskan bahwa kebahagiaan merupakan sesuatu yang sangat berharga, indah dan tak terlupakan. Hal ini senada dengan temuan Heady (2008) yang menyebutkan bahwa kebahagiaan merupakan tujuan hidup yang didamba oleh setiap orang. Dimensi yang keempat mengenai makna kebahagiaan adalah manfaat. Bagi remaja, kebahagiaan membuat hidup menjadi lebih berarti dan lebih indah, serta menggerakkan individu untuk terus melakukan sesuatu dalam hidupnya, bahkan menjadi kunci bagi kesuksesannya. Hal tersebut senada dengan penelitian Perneger, Hudelson dan Bovier (2004), serta penelitian Gilman dan Huebner (2006) yang menemukan korelasi kebahagiaan dengan kesehatan mental yang lebih baik dan meningkatnya fungsi intrapersonal individu. Temuan tersebut menunjukkan matangnya kemampuan remaja dalam merumuskan kebahagiaannya sendiri.

\section{DAFTAR RUJUKAN}

Anggraeny, A., Yuniarti, K.W., Moordiningsih, \& Kim, U. (2010). Happiness orientations among adolescents raised in urban and rural areas. Working Paper. Yogyakarta: CICP UGM.

Ben-Zur, H. (2003). Happy Adolescents : The Link Between Subjective Well-Being, Internal Resources, and Parental Factors. Journal of Youth and Adolescence, 32, 67-79.

Brockmann, H., \& Delhey, J. (2010). Introduction : The dynamics of happiness and the dynamics of happiness research. Social Indicator Research, 97, 1-5.

Cahyani, A.D. (2011). Sumber kebahagiaan yang dipersepsikan mahasiswa. Sebuah analisis jaringan. Tesis. Tidak diterbitkan. Yogyakarta: Program Magister Psikologi. Fakultas Psikologi UGM.

Casas, F., Coenders, G., Cummins, R.A., Gonzales, M., Figuer, C., \&Malo, S.C. (2008). Does subjective well-being show a relationship between parents \& their children? Journal of Happiness Study, 9, 197205.

Casas, F., Figuer, C., Gonza'lez, M., Malo, S., Alsinet, C., \& Subarroca, S. (2007). The well-being of 12 - to 16-year-old adolescents and their parents: Results from 1999 to 2003 Spanish samples. Social Indicators Research, 83, 87-115. 
Chaplin, J. (2006). Anger, happiness, and sadness : Associations with depresive symptoms in late adolescence. Journal of Youth and Adolescence, 35, 977-986.

Cheng, H., \&Furnham, A. (2001). Atributional Style and Personality as Predictors of Happiness and Mental Health. Journal of Happiness Studies, 2, 307-327.

Cheng, H., \& Furnham, A. (2004). Perceived Parental Rearing Style, Self Esteem and Self Criticism as Predictors of Happiness. Journal of Happines Studies, 5, 1-21.

Csikszentmihalyi, M., \& Hunter, J. (2003). Happiness in everyday life: The uses of experience sampling. Journal of Happiness Studies, 4, 185-199

Cummins, R.A., Lau, A.L.D., Mellor, D., \& Stokes, M.A. (2009). Encouraging governments to enhance the happiness of their nation: Understanding subjective wellbeing. Social Indicator Research, 91, 23-36.

Diener, E. (2009). Subjective Well-being. In Diener E. (Ed). The science of well-being..The collected works of Ed Diener. (pp 11-58). New York: Springer.

Gilman, R., \& Huebner, E.S. (2006). Characteristics of adolescents who report very high life satisfaction. Journal of Youth and Adolescence, 35, 311-319.

Hartati, N. (2012). Sumber-sumber kebahagiaan remaja yang tinggal di panti asuhan. Tesis. Tidak diterbitkan. Yogyakarta : UGM.

Heady, B. (2008). Life goals matter to happiness : A Revision of set-point theory. Social Indicator Research, $86,213-231$.

Honkanen, H.K., Honkanen, R. Koskenvuo, M., \& Kaprio, J. (2003). Self-reported happiness in life and suicide in ensuing 20 years. Social Psychiatry Epidemiology, 38, 244-248.

Koopmans, T.A., Geleijnse, J.M., \& Zitman, F.G.(2010) Effects of happiness on all-couse mortality during 15 years of follow-up : The arnhem elderly study. Journal of Happiness Study, 11, 113-124.

Magen, Z. (1999). Exploring adolescent happiness : Commitment, purpose and fulfillment. International journal for the Advancement of Counselling, 21, 367-369.

Oetami, P., Yuniarti, K.W., Moordiningsih, \& Kim, U. (2010). The orientation of happiness in male and female adolescent. Working Paper. Yogyakarta: CICP UGM.

Perneger, T.V., Hudelson, P.M., \& Bovier, P.A. (2004). Health and happiness in young Swiss adults. Quality of Life Research, 13, 171-178.

Primasari, A., Yuniarti, K.W., Moordiningsih, \& Kim, U. (2010). What make adolescents' happy? An exploratif approach of indigenous psychology. Working Paper. Yogyakarta : CICP UGM.

Setyasari, F.D. (2009). Peran Kelekatan, Kualitas Persahabatan dan Prestasi Akademik terhadap Kebahagiaan Hidup Remaja. Tesis. tidak diterbitkan. Yogyakarta : Program Magister Psikologi. Fakultas Psikologi UGM.

Snyder, C.R., \& Lopez, S.J. (2007). Positive psychology. The scientific and practical explorations of human strengths. California: Sage Publication.

Yang, A., Wang, D., Li, T., Teng, F., \& Ren, Z. (2008). The Impact of Adult Attachment and Parental Rearing on Subjective Well-Being in Chinese Late Adolescents. Social Behavior and Personality, 36, $1365-1378$. 